\title{
Tipologi Peran Stakeholder dalam Mendukung Reforestasi di Daerah Istimewa Yogyakarta
}

*Fatirahma Mustafa, Agam Marsoyo

${ }^{1}$ Departemen Teknik Arsitektur dan Perencanaan,Magister Perencanaan Wilayah dan Kota, Universitas Gadjah Mada

Email : fatirahma.09@gmail.com*, agam@ugm.ac.id

INFO ARTIKEL
Riwayat Artikel:
Diterima: 16-01-2020
Disetujui: 17-01-2020

Kata Kunci:

Hutan

Peran

Reforestasi

Stakeholder

Tipologi

\begin{abstract}
ABSTRAK
Abstrak: Reforestasi merupakan upaya yang dilakukan untuk memperbaiki kondisi tutupan hutan. Proporsi tutupan hutan di Daerah Istimewa Yogyakarta (DIY) pada tahun 2000 hanya sebesar $17,42 \%$ dari luas wilayah DIY yang mencakup tutupan hutan negara dan hutan hak. Kegiatan reforestasi dilakukan dalam rangka memperbaiki dan meningkatkan luas tutupan hutan di DIY. Tahun 2016, proporsi tutupan hutan di DIY mengalami peningkatan menjadi $31,63 \%$ dari luas wilayah DIY. Keberhasilan reforestasi terjadi dalam kurun waktu 16 tahun. Keberhasilan ini tidak lepas dari peran stakeholder yang terlibat dalam kegiatan reforestasi. Karenanya, analisis stakeholder menjadi penting dalam rangka merumuskan tipologi peran dari stakeholder yang terlibat dalam upaya reforestasi. Penelitian ini bertujuan untuk merumuskan tipologi peran stakeholder. Metode penelitian yang digunakan adalah metode penelitian induktif kualitatif dengan strategi studi kasus. Unit analisis pada penelitian ini adalah bentuk keterlibatan stakeholder yang kemudian akan dianalisis lebih lanjut sehingga akan dirumuskan menjadi tipologi peran stakeholder yang terlibat dalam mendukung reforestasi di DIY. Unit amatan analisis yang digunakan untuk menggambarkan keterlibatan stakeholder dalam upaya reforestasi di DIY ini terdiri dari 14 (empat belas) unit amatan yang didasarkan pada lokasi-lokasi terjadinya upaya reforestasi. Hasil penelitian menunjukkan bahwa terdapat 5 (lima) tipologi peran stakeholder yaitu peran stakeholder sebagai pembuat kebijakan, perencana, fasilitator, pelaksana, dan peneliti.
\end{abstract}

\begin{abstract}
Reforestation is a a kind of method in order to improve the condition of forest cover. Proportion of forest cover area in Yogyakarta Province in 2000 is 17,42\% of the total area of Yogyakarta Province which includes state forest cover and private forest. Kind of reforestation activities are carried out in order to improve and increase the area of forest cover in DIY. In 2016, proportion of forest cover area in Yogyakarta Province is $31,63 \%$ of the total area of Yogyakarta Province. The success of reforestation occurred within a period of 16 years. Stakeholders involved in various forms of involvement have a role in the success of reforestation. Therefore, stakeholder analysis becomes important in order to formulate a typology of the roles of stakeholders involved in reforestation. This study aims to find out the typology of stakeholder role. The research method was using an inductive qualitative research method with a case study strategy. The unit of analysis in this study was a form of stakeholder inquiry which would be further analyzed and then formulated into a typology of the roles of stakeholders involved in supporting reforestation in DIY. The observation unit of analysis used to describe stakeholder involvement in reforestation consists of 14 observation units based on the locations of reforestation. The results showed that typology roles of stakeholder are as policy creator, planner, facilitator, implementer, and researcher.
\end{abstract}

\section{A. LATAR BELAKANG}

Masalah yang paling mengkhawatirkan di abad ke21 ini, selain krisis ekonomi dan politik adalah krisis lingkungan. Ada berbagai faktor penyebabnya, yaitu banjir, tanah longsor, badai, gelombang panas, kebakaran hutan dan konversi lahan hutan. Dampak dari kebakaran hutan dan konversi areal hutan adalah timbulnya permasalahan kerusakan hutan (Hidayat, 2015). Besarnya ancaman terhadap kelestarian fungsi dan manfaat sumber daya hutan alam tropika Indonesia sejak lama telah tersaji di tengah-tengah ruang publik
(Fuad dkk, 2002). Hutan merupakan sumber daya alam yang memiliki banyak manfaat bagi kehidupan dan juga merupakan sumber daya alam yang keberadaannya menempati posisi sangat strategis dalam kehidupan berbangsa dan bernegara (Nandika, 2005). Keberadaan hutan dapat memberikan manfaat tidak hanya bagi aspek lingkungan, namun juga aspek sosial dan ekonomi.

Peningkatan jumlah penduduk, kebutuhan akan lahan-lahan terbangun mendorong masyarakat untuk memanfaatkan lahan hutan, baik lahan hutan hak yang merupakan hutan yang dibebani hak milik maupun 
hutan negara yang secara hukum telah ditetapkan oleh pemerintah. Tekanan pada hutan pun menjadi hal mutlak yang tidak bisa terhindarkan. Permasalahan mengenai kondisi hutan pada saat ini dapat dipahami sebagai keadaan yang tidak menguntungkan bagi kehidupan berbangsa dan bernegara. Hal ini tidak saja mengancam berbagai segi kehidupan bangsa, namun juga mengancam proses pembangunan berkelanjutan (sustainability development), dan menyebabkan hilangnya sumber-sumber pendapatan dan kehidupan (Nandika, 2005).

Kondisi alih fungsi lahan hutan tersebut perlu ditekan dan dikurangi secara bertahap, maka diperlukan kegiatan-kegiatan dalam rangka mempertahankan tutupan hutan atau yang dikenal dengan sebutan reforestasi. Reforestasi merupakan tantangan bagi pemulihan dan peningkatan pembangunan kehutanan. Sumber daya hutan merupakan sumber daya yang terbaharui (renewable resources), sehingga pada dasarnya kerusakan hutan tersebut dapat dipulihkan (Nandika, 2005). Pengelolaan hutan di Indonesia ini seyogyanya dilakukan dengan profesional dan terencana, sehingga dapat dimanfaatkan secara optimal, tanpa mengurangi kemampuan hutan untuk menghasilkan manfaat berkelanjutan bagi masyarakat lokal, nasional, regional, dan bahkan internasional (Alius, 2011).

Alius (2011) mengungkapkan bahwa Pemerintah Indonesia sudah mulai membenahi regulasi atau kebijakan yang dapat melindungi lingkungan hutan dari kemungkinan kepunahan, kerusakan, ataupun pencemaran akibat pelaksanaan pembangunan sosialekonomi. Regulasi yang diundangkan dalam rangka melindungi lingkungan hutan adalah Undang-Undang Nomor 41 Tahun 1999 tentang Kehutanan. Lebih lanjut, berdasarkan pasal 18 ayat (2) Undang-Undang 41 Tahun 1999 tersebut, luas kawasan hutan yang harus dipertahankan adalah minimal 30\% dari luas daerah aliran sungai dan atau pulau dengan sebaran yang proporsional. Dalam penjelasan pasal tersebut, disebutkan bahwa bagi provinsi dan kabupaten/kota yang luas kawasan hutannya diatas 30\% maka tidak boleh secara bebas mengurangi luas kawasan hutannya dari luas yang telah ditetapkan. Oleh sebab itu, luas minimal tidak boleh dijadikan dalih untuk mengkonversi hutan yang ada, melainkan sebagai peringatan kewaspadaan akan pentingnya hutan bagi kualitas hidup masyarakat. Sebaliknya, bagi provinsi dan kabupaten/kota yang luas kawasan hutannya kurang dari 30\% maka perlu menambah luas hutannya.

Berdasarkan Undang-Undang 41 Tahun 1999 disebutkan pula dalam pasal 5 ayat (1) bahwa hutan berdasarkan statusnya dibedakan menjadi 2, yaitu hutan negara dan hutan hak. Kawasan-kawasan hutan yang telah ditetapkan oleh negara pada hutan negara disebut dengan kawasan hutan. Daerah Istimewa Yogyakarta (DIY) merupakan provinsi di Indonesia yang luas kawasan hutannya berdasarkan ketetapan Menteri Kehutanan berada pada posisi nomor 2 terbawah. Luas kawasan hutan DIY berdasarkan ketetapan adalah \pm 19.037,61 $\mathrm{Ha}$ atau proporsinya hanya 5,98\% dari luas wilayah DIY, yang terbagi menjadi hutan konservasi, hutan lindung, dan hutan produksi. Kawasan hutan tersebut terbagi atas hutan konservasi seluas 3.312,66 Ha (15,98\%), hutan lindung seluas 2.312,80 Ha (12,36\%) dan hutan produksi seluas $13.411,70$ Ha $(71,66 \%)$. Fakta di lapangan menunjukkan bahwa kawasan hutan pada hutan negara tersebut tidak sepenuhnya tutupan lahannya hutan. Berdasarkan hasil analisis spasial tutupan lahan, data menunjukkan bahwa pada tahun 2000 luas hutan negara di DIY hanya sebesar 1.981,10 Ha, sedangkan di hutan hak hanya sebesar 53.505,50 Ha, sehingga bila dijumlah, maka luas hutan di DIY hanya sebesar 55.486,61 Ha atau $17,42 \%$ dari luas wilayah DIY. Penyebab sedikitnya luasan tutupan hutan ini adalah karena: (1) ketetapan luas kawasan hutan dari pemerintah yang tidak bisa diperluas lagi, ditambah dengan kenyataan dilapangan bahwa tutupan lahannya tidak sepenuhnya hutan, dan (2) adanya tindakantindakan deforestasi maupun konversi lahan hutan baik di hutan negara maupun hutan hak, terutama pasca era reformasi pada tahun 1998.

Dalam ranah nasional, mulai pertengahan tahun 1997, nilai berbagai mata uang Asia turun drastis terhadap dolar Amerika Serikat, yang dampaknya membawa Asia kedalam krisis ekonomi regional yang tidak pernah terjadi sebelumnya. Hal ini membawa dampak yang serius tidak saja pada sektor ekonomi, namun juga sektor kehutanan. Krisis ekonomi tersebut, membawa dampak adanya pengrusakan secara besarbesaran di hutan, termasuk hutan negara. Hal ini merupakan konsekuensi dari dimulainya era reformasi serta konflik sosial atas sumberdaya hutan.

Untuk memperbaiki kondisi hutan tersebut dan menaikkan jumlah tutupan lahan hutan, maka dilakukan upaya-upaya penanaman baik di hutan negara maupun hutan hak. Upaya-upaya penanaman tersebut lazim dikenal dengan sebutan reforestasi atau penghutanan kembali suatu wilayah. Upaya ini membuahkan hasil dalam kurun waktu 16 tahun. Berdasarkan hasil analisis data spasial, data menunjukkan bahwa pada tahun 2016 luas tutupan hutan di DIY adalah 100.766,98 Ha (31,63\% dari total luas wilayah DIY), yang terdiri dari 14.449,76 Ha hutan negara dan 86.317,22 Ha hutan hak (Lihat Gambar 1). 


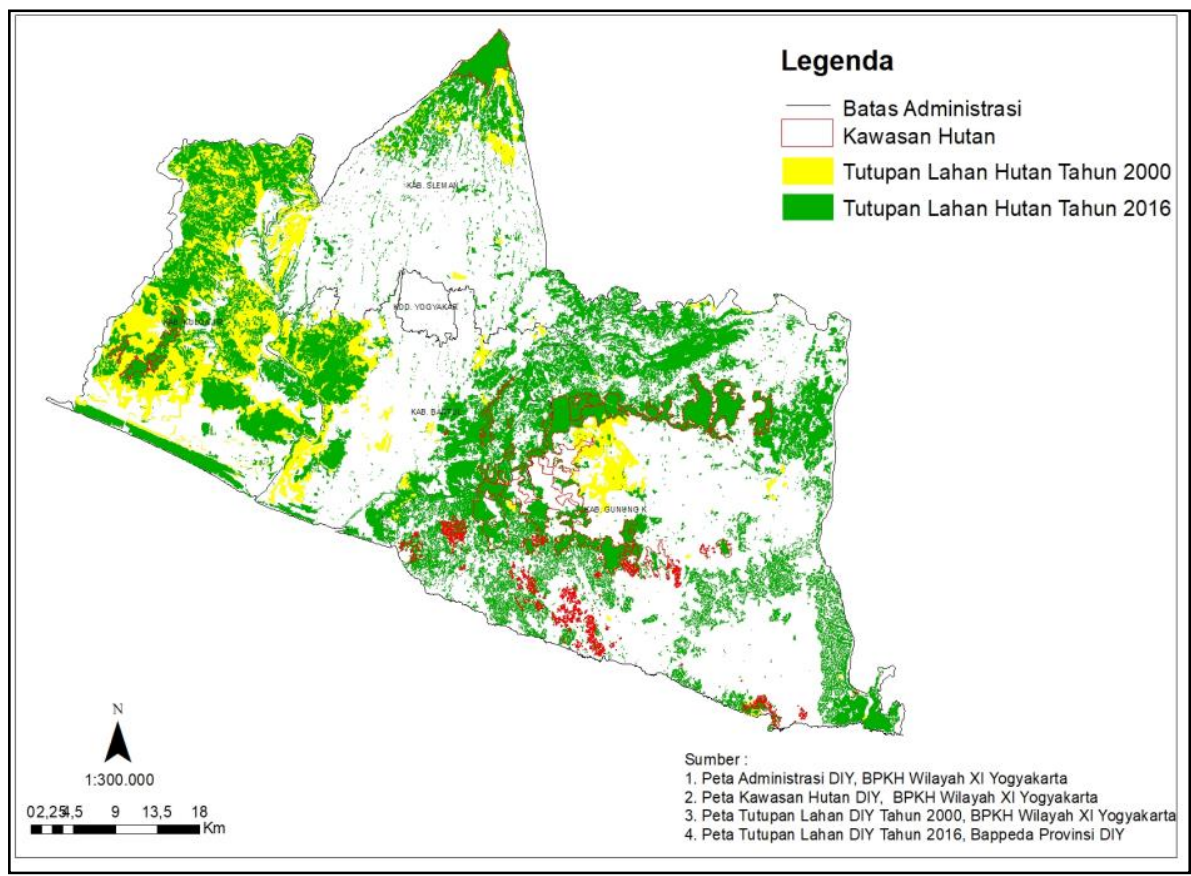

Gambar 1. Peta tutupan lahan hutan DIY Tahun 2000 \& 2016 Sumber : Analisis Peneliti, 2019

Barber dkk (1999) mengungkapkan tentang adanya suatu pandangan positif mengenai unsur-unsur pengelolaan hutan berkelanjutan yang baik. Pandangan tersebut berpangkal pada empat sendi, yaitu: (1) keutuhan dan kelanjutan ekologi, (2) penggunaan produk, dan jasa hutan oleh manusia secara berkelanjutan dan adil, (3) pengelolaan terpadu pada skala yang tepat, dan (4) keikutsertaan yang adil dan bijaksana oleh semua pihak yang berkepentingan. Dari empat pandangan tersebut, ada satu pandangan yang menarik, bahwasanya dalam pengelolaan hutan yang baik dibutuhkan keikutsertaan semua pihak yang berkepentingan. Fuad dkk (2002) menjelaskan bahwa saat ini pengelolaan sumber daya hutan di Indonesia sedang berada pada titik awal transformasi kultural, dimana diwarnai dengan keterlibatan banyak pihak dan berperan bersama-sama dalam pengaturan, pemanfaatan, pengawasan, dan pengelolaan hutan.

Keterlibatan pihak-pihak yang berkepentingan dalam pengelolaan hutan yang adil sesuai dengan porsinya masing-masing dapat menciptakan nuansa pengelolaan hutan yang berkelanjutan. Keterlibatan multipihak ini dimulai dari pengambilan keputusan sampai dengan pengimplementasiannya di lapangan. Keterlibatan para pemangku kepentingan dalam program kehutanan menyiratkan bahwa para pelaksana program tersebut harus mendorong terbentuknya hubungan yang konstruktif antara pemangku-pemangku kepentingan (Kusumanto dkk, 2006).

Penelitian-penelitian tentang reforestasi sebelumnya (Ginoga, 2007; Nagendra, 2007; Trabucco, 2008; Puspaningsih dkk, 2010; Innah dkk, 2012; Le dkk, 2014; Burney, 2015) telah memaparkan penelitian terkait reforestasi dari aspek kelembagaan, faktor pendorong, kebijakan, pemodelan, dan tantangan, namun terkait tipologi peran stakeholder dalam reforestasi masih belum dilakukan.

Berdasarkan uraian penjelasan diatas terkait fenomena reforestasi yang terjadi di DIY, menjadikan penelitian ini menjadi menarik untuk diteliti. Salah satu aspek yang perlu diteliti dalam reforestasi adalah peran stakeholder/pemangku kepentingan dalam mendukung upaya reforestasi, sehingga dapat disusun perencanaan pengelolaan hutan yang lebih komprehensif. Penelitian ini bertujuan untuk merumuskan tipologi peran stakeholder yang terlibat dalam mendukung upaya reforestasi di DIY.

\section{B. METODE PENELITIAN}

Pendekatan yang digunakan dalam penelitian ini adalah induktif kualitatif. Penelitian dengan pendekatan induktif kualitatif dilakukan melalui pengolahan data lapangan menjadi unit-unit informasi yang lebih abstrak. Pendekatan kualitatif dipilih berdasarkan pertimbangan bahwa pendekatan ini lebih peka dan lebih dinamis terhadap fakta-fakta dan nilai-nilai yang dihadapi di lapangan (Creswell, 2009). Strategi yang dilakukan adalah studi kasus. Unit analisis pada penelitian ini adalah bentuk keterlibatan stakeholder yang kemudian akan dianalisis lebih lanjut sehingga akan dirumuskan menjadi tipologi peran stakeholder yang terlibat dalam mendukung reforestasi di DIY.

Unit amatan analisis yang digunakan untuk menggambarkan keterlibatan stakeholder dalam upaya reforestasi di DIY terdiri dari 14 unit amatan yang didasarkan pada lokasi-lokasi terjadinya upaya reforestasi, baik di dalam hutan negara maupun hutan hak. Batasan waktu penelitian didasarkan pada upayaupaya reforestasi yang dilakukan oleh pihak-pihak terkait dalam kurun waktu tahun 2014-2019 atau dari tahun sebelumnya namun masih berlangsung sampai saat ini. Lokasi unit amatan sebagaimana yang tercantum dalam Tabel 1. 
Tabel 1

Unit Amatan Penelitian

\begin{tabular}{ll}
\hline No & \multicolumn{1}{c}{ Unit Amatan } \\
\hline Hutan Negara \\
\hline 1 & Restorasi di Taman Nasional Gunung Merapi \\
\hline 2 & Restorasi di Taman Hutan Raya Bunder \\
\hline 4 & Restorasi di Suaka Margasatwa Paliyan \\
& $\begin{array}{l}\text { Hutan Kemasyarakatan Mandiri di Kalibiru, } \\
\text { Kulon Progo }\end{array}$ \\
\hline 5 & Kemitraan Pengembangan Jati Unggul Nusantara \\
\hline 6 & Hutan Tanaman Rakyat KUD Bima \\
\hline 8 & Kawasan Hutan Dengan Tujuan Khusus \\
\hline Wanagama
\end{tabular}

Sumber: Analisis Peneliti, 2019

\section{HASIL DAN PEMBAHASAN}

Berdasarkan batasan yang telah ditentukan sebelumnya, diketahui bahwa dalam analisis terkait tipologi peran stakeholder ini akan dilihat pihak-pihak yang terlibat dalam upaya reforestasi dan sebagai apa keterlibatannya. Perlu dijelaskan pula bahwa makna stakeholder yang terlibat dalam reforestasi disini adalah pihak-pihak yang terlibat dalam mendukung reforestasi mulai dari perencanaan, pelaksanaan sampai dengan pengendalian.

Dari hasil penelitian, ditemukan terdapat 5 tipologi peran stakeholder yang terlibat dalam upaya reforestasi di DIY yaitu : (a) peran stakeholder sebagai pembuat kebijakan (policy creator), (b) peran stakeholder sebagai perencana (planner), (c) peran stakeholder sebagai fasilitator, (d) peran stakeholder sebagai pelaksana (implementer), dan (e) peran stakeholder sebagai peneliti (researcher). Berikut pembahasan mengenai hasil temuan tipologi peran stakeholder dari penelitian ini.

\section{Peran Stakeholder sebagai Pembuat Kebijakan (Policy Creator)}

Proses pembentukan tipologi peran stakeholder sebagai pembuat kebijakan (policy creator) diuraikan pada Gambar 2.

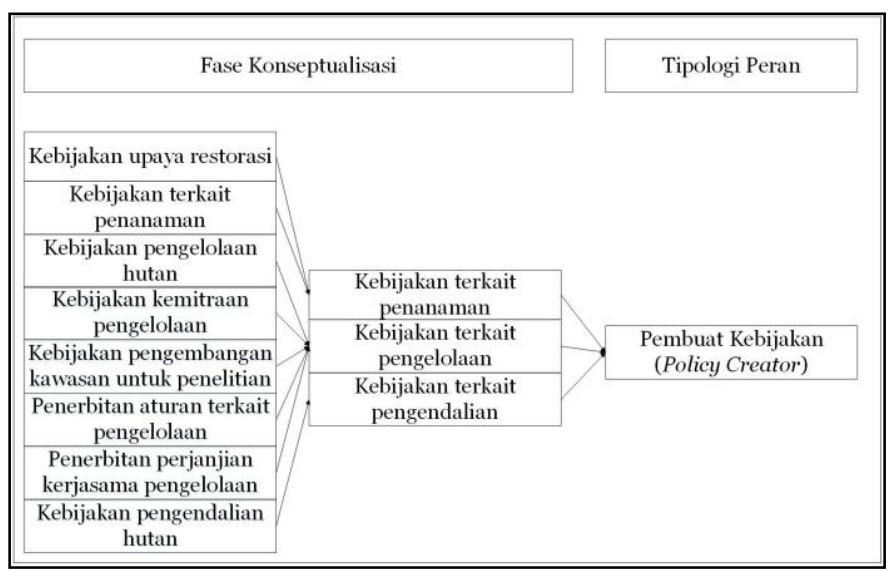

Gambar 2. Kategorisasi Tipologi Peran Stakeholder sebagai Pembuat Kebijakan (Policy Creator) Sumber : Analisis Peneliti, 2019

Terdapat 7 (tujuh) stakeholder yang memiliki peran sebagai pembuat kebijakan (policy creator), yaitu Balai Taman Nasional Gunung Merapi (Balai TNGM), Balai Konservasi Sumber Daya Alam DIY (BKSDA DIY), Balai Besar Penelitian dan Pengembangan Bioteknologi dan Pemuliaan Tanaman Hutan (Balai Besar Litbang BPTH), Dinas Lingkungan Hidup dan Kehutanan DIY (DLHK DIY), Balai Pengelolaan Taman Hutan Raya Bunder (Balai Pengelolaan Tahura Bunder), Pemerintah Desa Triwidadi, Pemerintah Desa Semoyo, dan Fakultas Kehutanan Universitas Gadjah Mada (Fakultas Kehutanan UGM). Stakeholder yang termasuk dalam kelompok pembuat kebijakan (policy creator) merupakan pihak-pihak yang berperan dalam membuat kebijakan untuk mendukung reforestasi di DIY.

Keterlibatan Balai TNGM sebagai pembuat kebijakan (policy creator) ditujukan dalam rangka melakukan reforestasi khususnya di Taman Nasional Gunung Merapi (TNGM). Reforestasi yang dilakukan di TNGM dikenal dengan istilah restorasi. Restorasi ini lebih optimal dilakukan pasca erupsi tahun 2010. Upaya restorasi ini dilakukan melalui beberapa kebijakan yang dikeluarkan misalnya pemilihan jenis tanaman yang harus ditanaman di kawasan TNGM merupakan jenis tanaman asli, dan juga adanya kebijakan penanaman harus dilakukan di zona rehabilitasi.

Keterlibatan BKSDA DIY sebagai pembuat kebijakan (policy creator) ditujukan dalam rangka melakukan reforestasi di kawasan konservasi, dimana dalam konteks penelitian ini adalah kawasan Suaka Margasatwa Paliyan. Reforestasi yang dilakukan di Suaka Margasatwa Paliyan dikenal dengan istilah restorasi. Upaya restorasi di Suaka Margasatwa Paliyan dihadapkan pada 2 masalah yaitu masalah konflik sosial masyarakat, dan permasalahan kondisi eksisting tutupan lahan hutan yang kritis. Berangkat dari permasalahan tersebut, BKSDA DIY berusaha untuk menetapkan kebijakan-kebijakan sebagai bagian dari resolusi konflik. Kebijakan yang diambil adalah kebijakan pengelolaan hutan-kebun dan juga pembentukan Forum Paliyan sebagai solusi permasalahan konflik sosial. Selain kebijakan tersebut, kebijakan lainnya yang diambil adalah skema kemitraan dengan PT. Mitsui Sumitomo Insurance. Kebijakan kemitraan ini diambil sebagai solusi terhadap permasalahan tutupan lahan yang kritis di Suaka Margasatwa Paliyan. 
Keterlibatan Balai Besar Litbang BPTH sebagai pembuat kebijakan (policy creator) ditujukan dalam rangka melakukan reforestasi di Kawasan Hutan Dengan Tujuan Khusus (KHDTK) Playen. Kebijakan yang dikeluarkan dimaksudkan untuk mendukung pengembangannya sebagai laboratorium alam dalam rangka menunjang kegiatan penelitian dan pengembangan di bidang kehutanan.

Keterlibatan DLHK DIY sebagai pembuat kebijakan (policy creator) ditunjukkan diantaranya dengan pembuatan surat keputusan maupun perjanjian kerjasama. Adapun beberapa surat keputusan maupun perjanjian kerjasama yang dikeluarkan yaitu: (a) Keputusan Dinas Kehutanan dan Perkebunan DIY Nomor 188/o8374 tahun 2017 tentang Penunjukan Daerah Penyangga Kawasan Pelestarian Alam Taman Hutan Raya Bunder, (b) Penetapan Keputusan Kepala Dinas Kehutanan dan Perkebunan DIY Nomor 188/305 tentang Penetapan Penyuluh Kehutanan Swadaya Masyarakat (PKSM) di DIY, (c) Perjanjian Kerjasama dengan Fakultas Kehutanan UGM Nomor 20/PERJ/GUB/XII/2018 tentang Pemanfaatan Taman Hutan Raya Bunder untuk Uji Coba Penanaman Cemara Udang (Casuarina equisetifolia), (d) Perjanjian Kerjasama dengan Balai Besar Penelitian dan Pengembangan Bioteknologi dan Pemuliaan Tanaman Hutan Nomor 23/PERJ/GUB/XII/2018 tentang Pemanfaatan Taman Hutan Raya Bunder Untuk Konservasi Ex-Situ Jenis Tanaman Langka, (e) Perjanjian Kerjasama dengan Balai Konservasi Sumber Daya Alam Yogyakarta Nomor 119/01186/II/2016 tentang Pengelolaan dan Pengembangan Stasiun Flora dan Fauna di Taman Hutan Raya (Tahura), (f) Perjanjian Kerjasama antara Dinas Kehutanan dan Perkebunan DIY dengan PT.Surya Silva Mataram Nomor 119/21370 tentang Pembangunan Hutan Tanaman Jati Melalui Inovasi Silvikultur Intensif dan Water Management. Dalam konteks hutan rakyat, kebijakan yang dikeluarkan hanya bersifat pengendalian dan pengereman agar masyarakat tetap semangat untuk menanam dan meminimalisir terjadinya alih fungsi lahan,

Pemerintah Desa Triwidadi dan Pemerintah Desa Semoyo juga memiliki peran sebagai pembuat kebijakan (policy creator). Kebijakan yang dikeluarkan berupa kebijakan-kebijakan yang bersifat himbauan dalam rangka meningkatkan kesadaran masyarakat desa untuk mengembangkan hutan rakyat dan dalam rangka pengendalian hutan rakyat tersebut.

Keterlibatan Fakultas Kehutanan UGM sebagai pembuat kebijakan (policy creator) ditujukan dalam rangka mendukung upaya reforestasi di Kawasan Hutan Dengan Tujuan Khusus (KHDTK) Wanagama. Kebijakan yang dikeluarkan oleh Fakultas Kehutanan adalah menetapkan jenis Acacia sebagai sumber nektar lebah kelompok tani lebah yang berada di desa-desa penyangga kawasan KHDTK Wanagama.

\section{Peran Stakeholder sebagai Perencana (Planner)}

Proses pembentukan tipologi peran stakeholder sebagai perencana (planner) diuraikan pada Gambar 3.

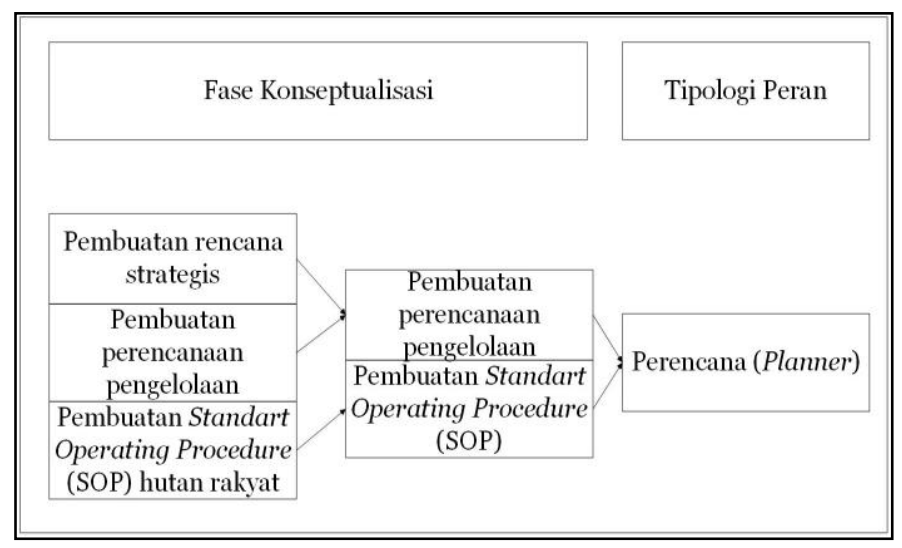

Gambar 3. Kategorisasi Tipologi Peran Stakeholder sebagai Perencana (Planner)

Sumber : Analisis Peneliti, 2019

Terdapat 14 stakeholder yang memiliki peran sebagai perencana (planner), yaitu Balai TNGM, BKSDA DIY, Balai Besar Litbang BPTH, Balai Pengelolaan Tahura Bunder, PT.Surya Silva Mataram, KUD Bima, Fakultas Kehutanan UGM, Kelompok Tani Hutan (KTH) Mandiri, KTH di Desa Kedungpoh, Serikat Petani Pembaharu Desa Semoyo, KTH di Desa Pundungsari, KTH di Desa Gayamharjo, KTH di Desa Triwidadi, KTH di Desa Sidorejo. Stakeholder yang termasuk dalam kelompok perencana (planner) merupakan pihak-pihak yang berperan dalam membuat perencanaan untuk mendukung reforestasi di DIY.

Keterlibatan Balai TNGM sebagai perencana (planner) dituangkan dalam rencana kegiatan. Rencana kegiatan ini memuat informasi mengenai perencanaan kegiatan yang dilakukan untuk mendukung restorasi di TNGM, mulai dari perencanaan penanaman, perencanaan pemeliharaan, sampai dengan perencanaan monitoring dan evaluasi pasca kegiatan restorasi tersebut.

Keterlibatan BKSDA DIY sebagai perencana (planner) ditunjukkan dengan pembuatan perencanaan penanaman, pemeliharaan dan pengayaan, pengembangan sarana dan prasarana, peningkatan kapasitas perlindungan kawasan, dan peningkatan kapasitas dan kesadaran masyarakat. Konsistensi perencanaan program ini juga berkontribusi dalam capaian pemulihan ekosistem.

Pihak lain yang memiliki peran sebagai perencana (planner) adalah Balai Besar Litbang BPTH. Perencanaan yang dilakukan adalah dalam rangka mengembangkan KHDTK Playen sebagai hutan penelitian.

Pihak lain yang juga memiliki peran sebagai perencana (planner) adalah Balai Pengelolaan Tahura Bunder. Dalam kaitannya dengan perencanaan reforestasi, pembangunan Tahura Bunder diskenario menggabungkan keistimewaan paleo ekosistem tersebut dengan skema kawasan pelestarian alam. Rehabilitasi dan juga pembangunan koleksi tanaman menjadi bagian penting dalam pembangunan jangka panjang, yang rencananya akan diimplementasikan simultan dengan pemanfaatan lainnya.

PT. Surya Silva Mataram dalam kaitannya sebagai perencana (planner), sesuai dengan perjanjian kerjasama antara Dinas Kehutanan dan Perkebunan DIY dengan PT. Surya Silva Mataram Nomor 119/21370 tentang Pembangunan Hutan Tamanan Jati Melalui 
Inovasi Silvikultur Intensif dan Water Management perlu melakukan perencanaan dalam pelaksanaan pembangunan hutan tanaman jati. Perencanaan tersebut dimulai dari tahapan penyiapan lahan, sampai dengan hasil akhirnya yaitu pemanenan dan penanaman kembali lagi.

Koperasi Unit Desa (KUD) Bima sebagai pemegang Izin Usaha Pemanfaatan Hasil Hutan Kayu pada Hutan Tanaman Rakyat (IUPHHKHTR) yang berlokasi di Desa Semanu, Kecamatan Semanu, Kabupaten Gunung Kidul memiliki peran sebagai perencana (planner). Hal ini dituangkan dengan pembuatan rencana pengelolaan/kerja izin usaha pemanfaatan hasil hutan kayu, dan rencana kerja tahunan. Rencana pengelolaan/kerja memiliki jangka waktu 10 tahun, sedangkan rencana kerja tahunan memiliki jangka waktu 1 tahun. Rencana tersebut memuat informasi mengenai rencana penanaman, sampai dengan pemeliharannya. Sejalan dengan KUD Bima, KTH Mandiri selaku pemegang Izin Usaha Pemanfaatan Hutan Kemasyarakatan (IUPHKm) Hutan Kemasyarakatan (HKM) Mandiri juga melakukan perencanaan dalam hal pengelolaan tersebut. Lokasi HKM Mandiri ini adalah di Pedukuhan Kalibiru, Desa Hargowilis, Kecamatan Kokap Kabupaten Kulonprogo, dengan total luas izin adalah 29 Ha. Rencana pengelolaan HKM Mandiri memuat informasi mulai dari penataan areal, konservasi perlindungan dan pengamanan hutan sampai dengan pengembangan kelembagaan.

Fakultas Kehutanan UGM juga merupakan pihak yang memiliki peran sebagai perencana (planner). Kegiatan perencanaan tersebut memuat informasi diantaranya pembibitan, penanaman, pemeliharaan, pengawasan, sampai dengan pemberdayaan masyarakat kawasan desa penyangga Wanagama.

Dari sisi pengembangan hutan rakyat, kelompok tani hutan (KTH) yang terbentuk sebagai wadah para petani hutan dalam pengelolaan hutan rakyat, juga memiliki peran sebagai perencana (planner) karena melakukan perencanaan dalam pengelolaan hutan rakyat mulai dari penentuan jenis yang akan ditanam, dan penentuan jarak tanam, sampai dengan pemeliharaan tanaman tersebut. Selain itu, terdapat juga KTH hutan rakyat yang membuat Standart Operating Procedure (SOP) sebagai bentu k perencanaan pengusahaan hutan rakyat, yaitu dalam pengembangan hutan rakyat di Desa Semoyo Kecamatan Patuk Kabupaten Gunung Kidul. SOP ini berisi pedoman-pedoman dalam hal manajemen kawasan hutan rakyat sekaligus juga tentang pengaturan jatah tebang, pembibitan, penaman, pemeliharaan, sampai dengan rencana kelola pengusahaan hutan rakyat.

\section{Peran Stakeholder sebagai Fasilitator}

Proses pembentukan tipologi peran stakeholder sebagai fasilitator diuraikan pada Gambar 4.

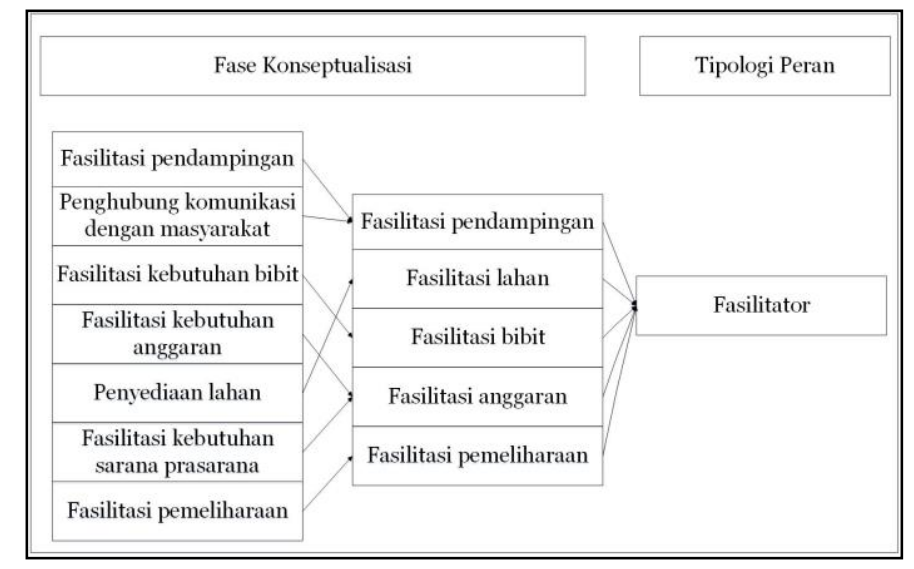

Gambar 4. Kategorisasi Tipologi Peran Stakeholder sebagai Fasilitator

Sumber : Analisis Peneliti, 2019

Terdapat 27 stakeholder yang memiliki peran sebagai fasilitator yaitu Balai TNGM, BKSDA DIY, Balai Besar Litbang BPTH, Balai Pengelolaan Daerah Aliran Sungai dan Hutan Lindung Serayu Opak Progo (BPDASHL Serayu Opak Progo), DLHK DIY, Balai Pengelolaan Tahura Bunder, Balai Kesatuan Pengelolaan Hutan (BKPH DIY), PT. Mitsui Sumitomo Insurance, PT. Surya Silva Mataram, PT. Bareka Duta Karsa, PDAM Sleman, KUD Bima, Yayasan Oemi, LSM Javlec, LSM Arupa, Yayasan Damar, Fakultas Kehutanan UGM, Australian Centre for International Agricultural Research (ACIAR), Kasultanan Yogyakarta, KTH mitra KUD Bima, KTH HKM Mandiri, KTH di Desa Kedungpoh, Serikat Petani Pembaharu Desa Semoyo, KTH di Desa Pundungsari, KTH di Desa Triwidadi, KTH di Desa Gayamharjo, dan KTH di Desa Sidorejo. Stakeholder yang termasuk dalam kelompok fasilitator merupakan stakeholder yang berperan untuk memfasilitasi dalam rangka mendukung terlaksana dan keberhasilan kegiatan reforestasi.

Balai TNGM dalam menjalankan perannya sebagai fasilitator ditunjukkan melalui kegiatan pendampingan di lapangan, fasilitasi bibit yang akan digunakan untuk penanaman, dan fasilitasi anggaran. Hal ini dilakukan untuk mendukung upaya restorasi di wilayah kerja TNGM.

Instansi lain yang juga berperan sebagai fasilitator adalah BPDASHL Serayu Opak Progo. Sebagai fasilitator, BPDASHL Serayu Opak Progo memiliki peran dalam hal penyediaan bibit untuk penanaman baik itu di lahan hutan negara maupun hutan hak. Kegiatan fasilitasinya berupa penyediaan bibit untuk kebun bibit rakyat (KBR), agroforestry, maupun penanaman di lahan kritis. Fokus dari kegiatan yang dilakukan oleh BPDASHL Serayu Opak Progo ini adalah terkait rehabilitasi hutan dan lahan.

Balai Besar Litbang BPTH juga merupakan salah satu pihak yang memiliki peran sebagai fasilitator. Keterlibatan instansi ini sebagai fasilitator terutama pada pemberian bibit untuk penanaman di areal tertentu, dimana difokuskan pada pemberian bibit unggul, dan juga fasilitasi anggaran. BKSDA DIY sebagai fasilitator, khususnya di kawasan konservasi memiliki peran antara lain memberikan fasilitasi bibit, anggaran, dan/atau pendampingan langsung ke lapangan.

DLHK DIY sebagai fasilitator berperan untuk memberikan bantuan bibit dalam rangka penanaman di hutan rakyat, dan juga pendampingan secara langsung 
di lapangan. Balai Pengelolaan Tahura Bunder sebagai fasilitator ditunjukkan melalui upaya balai ini untuk fasilitasi anggaran maupun bibit dalam mendukung upaya reforestasi di Tahura Bunder.

BKPH DIY memiliki peran sebagai fasilitator melalui pendampingan di lapangan. BKPH DIY sebagai pengelola kawasan tingkat tapak berusaha untuk memfasilitasi manajemen pengelolaan hutan secara keseluruhan, termasuk di dalamnya pengendalian izin.

Stakeholder swasta yang berperan sebagai fasilitator yaitu PT. Mitsui Sumitomo Insurance, PT.Surya Silva Mataram, dan PT. Bareka Duta Karsa. Pihak-pihak ini berperan dalam hal penyediaan anggaran untuk pembibitan, penanaman, pemeliharaan tanaman. Sebagai fasilitator, PT. Mitsui Sumitomo Insurance memegang peranan penting dalam mendukung kesuksesan upaya restorasi di Suaka Margasatwa Paliyan. Kunci keberhasilan ini karena PT. Mitsui Sumitomo Insurance secara konsisten menginisasi restorasi di Paliyan. Keterlibatan PT. Surya Silva Mataram sebagai fasilitator difokuskan pada fasilitasi penyiapan lahan untuk penanaman, pengadaan sarana prasarana dalam mendukung kegiatan penanaman, pengadaan bibit, sampai dengan fasilitasi kegiatan penanaman dan pemeliharaan tanaman. Selain itu, mereka juga berupaya untuk melakukan pemberdayaan di masyarakat mengingat tujuan dari adanya kemitraan yang dilakukan oleh PT.Surya Silva Mataram ini adalah untuk membangun hutan tanaman jati yang lestari dan berkelanjutan melalui pemberdayaan masyarakat. Hal ini sesuai dengan kewajiban-kewajiban PT.Surya Silva Mataram sebagai mitra dalam pengembangan jati unggul nusantara di hutan produksi yang tertuang dalam perjanjian kerjasama. Keterlibatan PT. Bareka Duta Karsa sebagai fasilitator ditunjukkan dengan adanya fasilitasi anggaran dan sarana prasarana untuk mendukung penanaman di HTR KUD Bima.

Keterlibatan PDAM Sleman sebagai fasilitator ditujukan dalam rangka mendukung upaya restorasi di Taman Nasional Gunung Merapi (TNGM). Upaya ini dilakukan dalam rangka memperingati hari ulang tahun PDAM sekaligus juga merupakan gerakan konservasi sumber mata air, mengingat salah satu sumber mata air sebagai bahan baku usaha PDAM ada di dalam kawasan TNGM.

KUD Bima selaku unit bisnis daerah juga merupakan pihak yang berperan sebagai fasilitator dalam mendukung reforestasi di HTR Bima. KUD Bima melalui wadah kelembagaannya memfasilitasi jalannya kegiatan reforestasi di HTR Bima. Hal ini mengingat dalam mendukung operasionalisasi kegiatan HTR, diperlukan adanya suatu kelembagaan yang resmi. Pada saat itu, perizinan HTR diberikan kepada KUD Bima sebagai unit bisnis daerah (koperasi) yang sudah ada di wilayah tersebut. KTH yang terlibat sebagai mitra KUD Bima yaitu KTH Jati Lestari dan KTH Paman Polah.

Selain pihak-pihak diatas, pihak lain yang juga berperan sebagai fasilitator adalah dari kelompok lembaga swadaya masyarakat (LSM). LSM yang berperan sebagai fasilitator dalam mendukung reforestasi di DIY antara lain Yayasan Oemi, LSM Javlec, LSM Arupa, dan Yayasan Damar. Sebagai fasilitator, Yayasan Oemi lebih berfokus pada fasilitasi anggaran untuk mendukung reforestasi di KHDTK Wanagama. Keterlibatan LSM Javlec sebagai fasilitator di KHDTK Wanagama ditunjukkan melalui fasilitasi pemotretan tutupan lahan terkini di KHDTK Wanagama. Adapun LSM Arupa melakukan fasilitasi pendampingan dalam rangka pengembangan hutan rakyat menuju pengelolaan yang lestari dan berkelanjutan. LSM Arupa melakukan fasilitasi pendampingan dalam memperoleh sistem verifikasi legalitas kayu (SVLK) di Desa Gayamharjo Kabupaten Sleman, Desa Triwidadi Kabupaten Bantul, dan Desa Semoyo Kabupaten Gunung Kidul. Selain pendampingan tersebut, upaya fasilitasi lain yang dilakukan oleh LSM Arupa adalah berupa penyebaran informasi mengenai informasi bibit yang dapat diakses oleh petani untuk penanaman. Keterlibatan Yayasan Damar sebagai fasilitator ditunjukkan melalui upaya pendampingan dalam pengembangan HKM Mandiri di Kalibiru, Kabupaten Kulon Progo, dan juga melalui bantuan untuk mencarikan bibit yang dapat digunakan untuk penanaman di wilayah tersebut

Kelompok stakeholder akademisi yang berperan sebagai fasilitator adalah Fakultas Kehutanan UGM dan Australian Centre for International Agricultural Research (ACIAR). Keterlibatan Fakultas Kehutanan UGM sebagai fasilitator ditunjukkan dalam upaya reforestasi di TNGM, Tahura Bunder, KHDTK Wanagama, dan Suaka Margasatwa Paliyan. Fasilitasi yang dilakukan berupa pendampingan penelitian uji genetik vegetasi, fasilitasi anggaran, maupun fasilitasi bibit. Dalam upaya restorasi di TNGM, fasilitasi yang dilakukan oleh Fakultas Kehutanan UGM adalah melalui fasilitasi bibit dengan pembuatan demplot percontohan.Senada dengan apa yang dilakukan di TNGM, Fakultas Kehutanan UGM juga memberikan fasilitasi bibit untuk mendukung restorasi di Suaka Margasatwa Paliyan. Upaya ini dilakukan untuk mendapatkan jenis-jenis asli (native) penyusun hutan karst. Skemanya adalah penelitian unggulan perguruan tinggi, reintroduksi spesies asli (native) karst. Tujuannya adalah untuk mengetahui jenis-jenis asli penyusunan hutan karst ini. Keterlibatan ACIAR sebagai fasilitator ditunjukkan melalui fasilitasi anggaran maupun bibit unggul dalam rangka proyek penelitian penanaman Acacia di KHDTK Playen.

Kasultanan merupakan pihak lain yang juga berperan sebagai fasilitator. Sebaran lahan di DIY selain lahan milik, juga ada yang namanya tanah sultan (sultan ground), yaitu lahan-lahan yang dimiliki oleh Sultan. Pengembangan hutan rakyat di DIY ini selain di lahan milik juga ada yang dilakukan di tanah sultan (sultan ground), contohnya adalah pengembangan hutan rakyat dengan pola agroforestry di Desa Pundungsari Kabupaten Gunung Kidul seluas 10 Ha. Dalam konteks ini, peran Kasultanan sebagai fasilitator adalah penyedia lahan yang dapat digunakan oleh masyarakat untuk pengembangan hutan rakyat tersebut. Pemanfaatan lahan ini selain untuk tujuan reforestasi juga untuk meningkatkan kesejahteraan masyarakat.

Keterlibatan kelompok tani hutan (KTH) sebagai fasilitator ditujukan untuk mendukung upaya reforestasi baik di hutan negara maupun hutan hak (hutan rakyat). Bentuk fasilitasi yang diberikan adalah berupa fasilitasi bibit, fasilitasi anggaran, maupun fasilitasi lahan. Fasilitasi lahan dilakukan oleh KTH yang melakukan upaya reforestasi di lahan milik, dalam bentuk hutan rakyat. Pada upaya reforestasi di hutan negara dengan melibatkan KTH, dimana dalam konteks penelitian ini adalah HTR Bima dan HKM Mandiri, upaya fasilitasi yang dilakukan adalah berupa penyediaan bibit dan 
anggaran. KTH yang menjadi mitra dalam HTR KUD Bima ada 2 (dua) yaitu KTH Paman Polah dan KTH Jati Lestari. Sedangkan KTH sebagai penanggungjawab izin kelola HKM Mandiri adalah KTH Mandiri.

Sedangkan pada pengembangan hutan rakyat, kelompok tani hutan yang ada memiliki peran tidak hanya dalam hal penyediaan bibit maupun anggaran, namun juga dalam hal penyediaan lahan. Hal ini mengingat bahwa pengembangan hutan rakyat dilakukan di lahan milik. Hal ini menunjukkan bahwa dalam pengembangan hutan rakyat lebih menitikberatkan pada swadaya masyarakat. Masyarakat sebagai pemiliki lahan, memfasilitasi lahannya sendiri untuk penanaman tanaman keras, termasuk juga dalam hal pembibitan, maupun pemeliharaan. Jikapun ada bantuan dari pemerintah, itu hanya bersifat optional saja.

\section{Peran Stakeholder sebagai Pelaksana (Implementer)}

Proses pembentukan tipologi peran stakeholder sebagai pelaksana (implementer) diuraikan pada Gambar 5 .

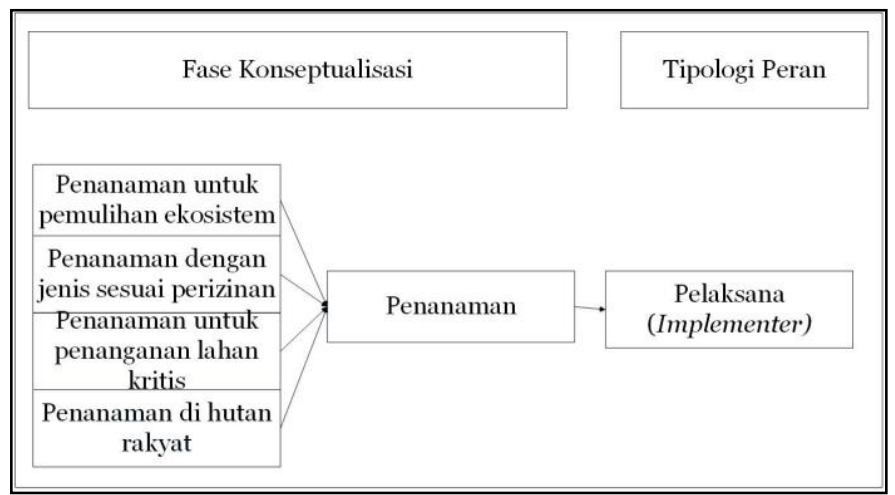

Gambar 5. Kategorisasi Tipologi Peran Stakeholder sebagai Pelaksana (Implementer)

Sumber: Analisis Peneliti, 2019

Terdapat 15 stakeholder yang memiliki peran sebagai pelaksana (implementer). Stakeholder tersebut antara Balai TNGM, BKSDA DIY, Balai Besar Litbang BPTH, DLHK DIY, Balai Pengelolaan Tahura Bunder, PT. Surya Silva Mataram, Fakultas Kehutanan UGM, KTH mitra HTR KUD Bima, KTH mitra PT. Surya Silva Mataram, KTH HKM Mandiri, KTH di Desa Kedungpoh, Serikat Petani Pembaharu Desa Semoyo, KTH di Desa Pundungsari, KTH di Desa Triwidadi, KTH di Desa Gayamharjo, dan KTH di Desa Sidorejo. Stakeholder yang termasuk dalam kelompok pelaksana (implementer) merupakan pihak-pihak yang berperan dalam melaksanakan/ mengimplementasikan upaya-upaya untuk reforestasi di lapangan. Dalam kaitannya dengan reforestasi, pihak-pihak yang terlibat sebagai pelaksana (implementer) memiliki peran sebagai aktor/pelaku yang melakukan kegiatan penanaman langsung di lapangan. Balai TNGM, BKSDA DIY, Balai Besar Litbang BPTH, Balai Pengelolaan Tahura Bunder berperan sebagai pelaksana (implementer), karena secara tugas pokok dan fungsinya, instansi-instansi tersebut memiliki kewenangan pengelolaan pada masing-masing kawasan.

PT. Surya Silva Mataram juga merupakan salah satu pihak yang berperan sebagai pelaksana (implementer). Kedudukan perusahaan ini sebagai pelaksana merupakan bentuk pengimplementasian dari kewajiban yang dituliskan dalam perjanjian kerjasama. Berdasarkan perjanjian kerjasama yang ada, PT.Surya Silva Mataram memiliki kewajiban untuk melakukan penanaman dan pemeliharaan. Kemudian dalam membantu pelaksanaannya di lapangan, perusahaan ini juga melibatkan kelompok tani hutan sebagai mitra, mengingat tujuan dari adanya kerjasama ini adalah untuk pemberdayaan dan peningkatan kesejahteraan masyarakat. Terdapat 3 (tiga) kelompok tani yang bermitra dengan PT. Surya Silva Mataram, yaitu KTH Ngudi Makmur, KTH Lestari Widodo, dan KTH Sumber Wanajati Kepek 2.

Fakultas Kehutanan UGM merupakan akademisi yang memiliki kewenangan dalam hal pengelolaan di KHDTK Wanagama. Hal ini dimaksudkan untuk mengembangkan hutan Wanagama ini menjadi hutan penelitian di DIY. Implikasinya adalah Fakultas Kehutanan UGM juga perlu terjun langsung untuk melakukan penanaman di KHDTK Wanagama tersebut.

Kegiatan reforestasi di HTR KUD. Bima dilakukan oleh KTH Jati Lestari dan KTH Paman Polah. Berdasarkan perizinan yang ada, KTH tersebut dalam pengelolaannya diwajibkan melakukan kegiatan usaha pemanfaatan hasil hutan kayu pada hutan tanaman rakyat yang meliputi kegiatan penyiapan lahan, pembibitan, penanaman, pemeliharaan, pemanenan, pemasaran hasil hutan kayu, dan penanaman kembali pasca pemanenan. Reforestasi di HKM Mandiri dilakukan oleh KTH Mandiri yang memiliki kewajiban untuk menanam tanaman pokok dan tanaman kebun, serta menjaga pohon yang berada di kawasan hutan yang menjadi kewenangannya.

Dalam pengelolaan hutan rakyat, pihak yang langsung terjun ke lapangan untuk melakukan upayaupaya reforestasi adalah kelompok tani hutan (KTH) hutan rakyat. KTH hutan rakyat ini memiliki peranan sebagai pelaksana dalam upaya penanaman maupun pemeliharaan tanaman yang ada di lahan miliknya.

\section{Peran Stakeholder sebagai Peneliti (Researcher)}

Proses pembentukan tipologi peran stakeholder sebagai peneliti (researcher) diuraikan pada Gambar 6.

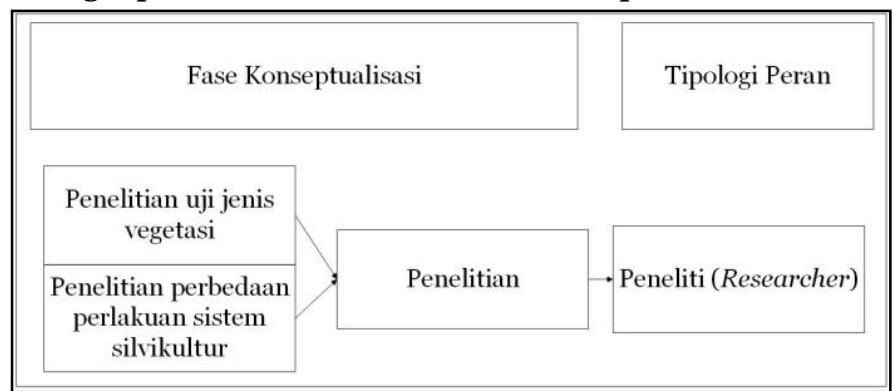

Gambar 6. Kategorisasi Tipologi Peran Stakeholder sebagai Peneliti(Researcher)

Sumber: Analisis Peneliti, 2019

Terdapat 3 (tiga) stakeholder yang memiliki peran sebagai peneliti (researcher), yaitu Balai Besar Litbang BPTH, Fakultas Kehutanan UGM, dan ACIAR. Stakeholder yang termasuk dalam peneliti (researcher) merupakan pihak-pihak yang berperan dalam melakukan penelitian untuk mendukung keberhasilan reforestasi.

Keterlibatan Balai Besar Litbang BPTH dalam hal penelitian ditujukan untuk mendukung upaya reforestasi 
di KHDTK Playen dan Tahura Bunder. Upaya yang dilakukan adalah penelitian melalui uji penanaman jenis-jenis unggul. Keterlibatan Balai Besar Litbang BPTH dalam mendukung upaya restorasi di Tahura Bunder melalui penanaman jenis unggul didasarkan pada Perjanjian Kerjasama Nomor 23/PERJ/GUB/XII/2018 tentang Pemanfaatan Taman Hutan Raya Bunder Untuk Konservasi Ex-Situ Jenis Tanaman Langka.

Keterlibatan Fakultas Kehutanan UGM sebagai peneliti (researcher) ditujukan untuk mendukung upaya reforestasi di beberapa lokasi penelitian, yaitu KHDTK Wanagama, TNGM, Suaka Margasatwa Paliyan, dan Tahura Bunder. Keterlibatan Fakultas Kehutanan UGM untuk mendukung upaya reforestasi di KHDTK Wanagama ditunjukkan melalui upaya-upaya penelitian penanaman, pembuatan kebun persemaian untuk melakukan penelitian, dan lain-lain. Pada TNGM keterlibatan Fakultas Kehutanan UGM sebagai peneliti (researcher) ditunjukkan melalui pembuatan demplot percontohan sebagai media penelitian. Pada Suaka Margasatwa Paliyan keterlibatan Fakultas Kehutanan UGM sebagai peneliti (researcher) ditunjukkan melalui penelitian reintroduksi spesies asli (native) karst di Suaka Margasatwa Paliyan. Sedangkan pada Tahura Bunder, keterlibatan Fakultas Kehutanan UGM sebagai peneliti ditunjukkan melalui upaya uji coba penanaman cemara udang (Casuarina equisetifolia) sesuai dengan Perjanjian Kerjasama Nomor 20/PERJ/GUB/XII/2018 tentang Pemanfaatan Taman Hutan Raya Bunder untuk Uji Coba Penanaman Cemara Udang (Casuarina equisetifolia)

\section{Konseptualisasi Tipologi Peran Stakeholder}

Berdasarkan hasil pembahasan diatas, diketahui bahwa terdapat 5 (lima) tipologi peran stakeholder yang terlibat dalam reforestasi, yaitu sebagai pembuat kebijakan (policy creator), perencana (planner), fasilitator, pelaksana (implementer), dan peneliti (researcher). Kelima tipologi peran stakaholder ini yang saling berintegrasi dalam mendukung upaya reforestasi di DIY. Secara lengkap konseptualisasi dan rekapitulasi tipologi peran stakeholder dapat dilihat pada Gambar 7.

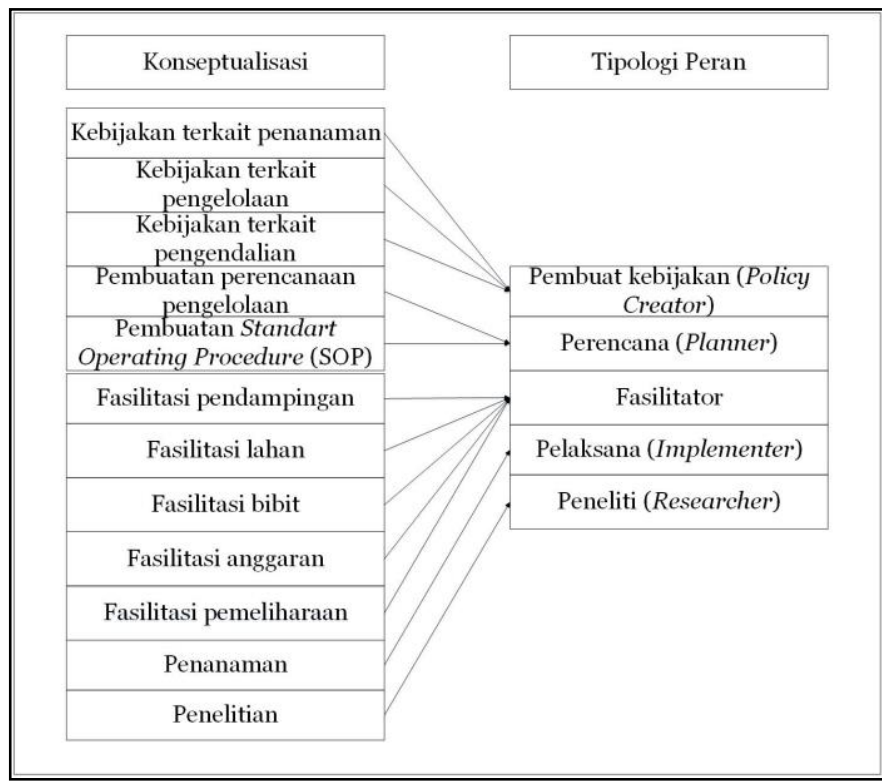

Gambar 7. Konseptualisasi Tipologi Peran Stakeholder Sumber: Analisis Peneliti, 2019
Stakeholder yang berperan sebagai pembuat kebijakan (policy creator) memiliki peranan dalam hal mengeluarkan kebijakan dan berupa himbauan yang bersifat pengendalian, serta mengeluarkan izin pengelolaan dalam hal mendukung reforestasi. Stakeholder yang berperan sebagai perencana (planner) memiliki peranan dalam hal membuat rencana kerja pengelolaan hutan sebagai bentuk implementasi dari apa yang telah diterbitkan oleh pembuat kebijakan (policy creator).

Stakeholder yang berperan sebagai fasilitator memiliki peranan dalam hal memfasilitasi segala kegiatan untuk mendukung reforestasi. Bentuk fasilitasi yang dilakukan dapat berupa fasilitasi lahan, fasilitasi bibit, fasilitasi anggaran, maupun fasilitasi berupa pendampingan dalam rangka peningkatan kapasitas sumber daya manusia di lapangan.

Stakeholder yang berperan sebagai pelaksana (implementer) merupakan ujung tombak terealisasinya suatu kegiatan reforestasi di lapangan, karena pelaksana ini merupakan pihak-pihak yang terjun langsung dan melakukan kegiatan reforestasi tersebut. Sejalan dengan pelaksana, peneliti (researcher) memiliki peranan dalam mengimplementasikan kegiatan reforestasi di lapangan sekaligus melakukan penelitian untuk mendukung kegiatan reforestasi tersebut.

\section{SIMPULAN DAN SARAN}

Berdasarkan hasil pembahasan diatas dapat disimpulkan bahwa dalam mendukung upaya reforestasi di DIY, terdapat 5 tipologi peran stakeholder yang terlibat, yaitu peran stakeholder sebagai pembuat kebijakan (policy creator), perencana (planner), fasilitator, pelaksana (implementer), dan peneliti (researcher). Keterlibatan stakeholder dengan kelima peran stakeholder tersebut yang saling berkolaborasi dalam mendukung upaya reforestasi di DIY. Dapat dianalogikan bahwa kebijakan yang telah dibuat oleh pembuat kebijakan (policy creator) dapat diterjemahkan dengan baik dalam suatu program/kegiatan oleh perencana (planner), kemudian difasilitasi pelaksanaannya di lapangan oleh fasilitator, selanjutnya diimplementasikan dengan baik di lapangan oleh pelaksana (implementer), dan didukung pula oleh ketersediaan peneliti (researcher) untuk mendukung penelitian dalam menemukan inovasi-inovasi reforestasi untuk masa yang akan datang.

Penelitian ini membahas secara umum tipologi peran stakeholder dari 14 unit amatan yang menjadi fokus penelitian. Untuk mendapatkan hasil yang lebih komprehensif dalam menggambarkan peran stakeholder yang terlibat pada upaya reforestasi di DIY, maka peneliti menyarankan perlu dilakukan penelitian selanjutnya dengan unit amatan yang berbeda dan lebih kompleks sehingga dapat menggambarkan tipologi peran serta stakeholder dalam mendukung reforestasi di DIY secara menyeluruh.

\section{UCAPAN TERIMA KASIH}

Peneliti mengucapkan terima kasih kepada Pusat Pembinaan, Pendidikan dan Pelatihan Perencana Bappenas (Pusbindiklatren) selaku pihak yang memberikan beasiswa dan bantuan untuk penelitian ini. Tidak lupa peneliti mengucapkan terima kasih pula 
kepada instansi baik instansi pusat maupun daerah, pihak swasta, pihak LSM, dan pihak organisasi masyarakat yang telah membantu selesainya proses penelitian ini.

\section{DAFTAR RUJUKAN}

[1] Alius, S. (2011). Masa Depan Hutan Indonesia Rumusan Komprehensif Terhadap Pengelolaan Kawasan Hutan. Jakarta: Pensil-324.

[2] Barber, Victor Charles. (1999). Menyelamatkan Sisa Hutan di Indonesia dan Amerika Serikat. Jakarta: Yayasan Obor Indonesia

[3] Burney, Owen T., Rafael Alvarez Reyes; Arnulfo Aldrete, Jose Angel Prieto-Ruiz. (2015). Mexico-Addressing Challenges to Reforestation. Journal of Forestry, 404-413. doi:10.5849/jof.14-007.

[4] Creswell, J. (2009). Research Design Qualitative, Quantitative, and Mixed Methods Approaches. California: Sage Publications,Inc.

[5] Devkota, R. R. (2010). Interests and Power as Drivers of Community Forestry (A Case Study of Nepal). Gottingen: Universitatsverlag Gottingen.

[6] Fuad, Faisal H., Hendri A. Susanto, Agus Prijono. (2002). Tangan-Tangan Negara Menggenggam Hutan. Yogyakarta: Biro Penerbitan Arupa.

[7] Ginoga, Kirsfianti, dan Deden Djaenudin. (2007). Kinerja Reforestasi pada Kabupaten dengan Kondisi Sosial Ekonomi Berbeda di Nusa Tenggara Timur. Jurnal Penelitian Sosial dan Ekonomi Kehutanan, Vol.4 No.1, 118. doi:10.20886/jpsek.2007

[8] Ginoga, Kirsfianti Linda, Mega Lugina, dan R. Deden Djaenudin. (2007). Kelembagaan Aforestasi dan Reforestasi Mekanisme Pembangunan Bersih (A/R MPB) di Indonesia : Kasus di Nusa Tenggara Barat dan Jawa Barat. Jurnal Penelitian Sosial dan Ekonomi Kehutanan, Vol.4 No.2, 137-161. doi:10.20886/jpsek.2007.4.2.137-161.

[9] Hidayat, H. (2015). Pengelolaan Hutan Lestari : Partisipasi, Kolaborasi, dan Konflik. Jakarta: Buku Obor.

[10] Innah, Henry Silka, Arya Hadi Dharmawan, Didik Suharjito, Dudung Darusman. (2012). Peran Dinamika Jejaring-Aktor Dalam Reforestasi di Papua. Jurnal Penelitian Sosial dan Ekonomi Kehutanan, Vol. 9 No.2, 96-112. doi:10.20886/jpsek.2012.9.2.96-112

[11] Kang, Mihee, dan Seongil Kim. (2015). Development of North Korea's Reforestation Strategies Through Benchmarking Six Asian Countries' Cases. Forest Science and Technology, Vol. 11,No.2, 104-110. doi: 10.1080/21580103.2014.966864

[12] Kusumanto, Trikurnianti, Elizabeth Linda Yuliani, Phil Macoun, Yayan Indriatmoko, dan Hasantoha Adnan. (2006). Belajar Beradaptasi Bersama-Sama Mengelola Hutan di Indonesia. Jakarta: Centre for International Forestry Research (CIFOR).

[13] Le, Hai Dinh, Carl Smith, dan John Herbohn. (2014). What Drives the Success of Reforestation Project in Tropical Developing Countries? THe Case of The Philippines. Elsevier (Global Environmental Change), 334-348.

[14] Nagendra, H. (2007). Drivers of Reforestation in HumanDominated Forest. Proceedings of The National Academy of Sciences of The United States of America, Vol. 104, 39.

[15] Nandika, D. (2005). Hutan Bagi Ketahanan Nasional. Surakarta: Muhammadiyah University Press.

[16] Puspaningsih, Nining, Kukuh Murtilaksono, Naik Sinukaban, I Nengah Surati Jaya, dan Yadi Setiadi. (2010). Pemantauan Keberhasilan Reforestasi di Kawasan Pertambangan Melalui Model Indeks Tanah. Jurnal Manajemen Hutan Tropika, Vol. XVI, (2), 53-62. doi: 10.7226/jmht.16.2
[17] Sudjito. (2017). Kehutanan : Analisis dan Refleksi Yuridis-Filosofis Problema Kehutanan di Indonesia. Yogyakarta: Dialektika

[18] Trabucco, Antonio, Deborah Ann Bossio, Robert John Zomer, dan Oliver van Straaten. (2008). Climate Change Mitigation Through Afforestation/Reforestation : A Global Analysis of Hydrologic Impacts With Four Case Studies. Elsevier (Agriculture Ecosystems \& Environment), 126, 81-97. doi: 10.1016/j.agee.2008.01.015. 